\title{
Seasonal influence on centesimal composition and yield of Amazonian fish
}

\author{
Alexandre Augusto BARAI ${ }^{1 *}$ (D), Antônio Fábio Lopes de SOUZA², Adriana Pontes VIANA ${ }^{1}$, \\ Antônio José INHAMUNS²
}

\begin{abstract}
The objective of this study was to evaluate meat yield and centesimal composition of the Amazonian fish species, A. ocellatus, $P$. castelnaeana, and $L$. friderici, in the dry and flood seasonal cycles of rivers. In each seasonal cycle (flood and dry), a total of 60 fish were collected, comprising 20 specimens of each of the following species: A. ocellatus, P. castelnaeana, and L. friderici. Were evaluated the meat yield, cuts yield and centesimal composition of the fish samples. Meat yield in the clean body cuts and skinless filet varied between species and hydrological period. The results showed that seasonal variation influenced the centesimal composition and yield of the species studied, with significant differences between the cuts produced during processing. These findings highlight the need to apply a variety of technological processes to ensure efficient use of these species throughout the year. The total waste represented more than $50 \%$ of the whole fish, and the head size was directly proportional to the amount of waste generated. These results underscore the importance of waste utilization for animal and/or human nutrition.
\end{abstract}

Keywords: Astronotus ocellatus; fish meat yield; fish processing; Pellona castelnaeana; Leporinus friderici.

Practical Application: There is a lot of information's in the literature about meat yield and centesimal composition of native Brazilian fishes. However, these studies especially concentrate in the main commercial species. The study performed served to attend the demand to information's about species of Amazonian fishes as alternative commercial.

\section{Introduction}

In many parts of the world, fish forms a fundamental component of the human diet and is the main source of animal protein (Goes et al., 2016; Temesgen et al., 2019). The nutritional benefits of fish include high content and quality of proteins and lipids; vitamins A, D, and B complex; and minerals (Ogawa, 1999; Goes et al., 2016; Mafra et al., 2016; Araújo et al., 2018).

Although fish consumption in Brazil has increased, it is still low overall, with a per capita consumption of approximately $14.5 \mathrm{~kg} / \mathrm{kg} /$ inhabitant/year. The intake of fish in the country reflects regional cultural differences, quantity, and the quality available, as well as the low prices of alternative products that influence consumer choice at the time of purchase (Lopes et al., 2010; Lira et al., 2019; Verdi et al., 2020). However, in the Brazilian Amazon, which has an estimated average consumption of $369 \mathrm{~g} /$ inhabitant/day in the lower Solimões River areas and up to $135 \mathrm{~kg} /$ inhabitant/year in the upper Amazon, fish consumption rate exceeds that of many parts of the world. It is the main protein source for populations that live on the banks of the Amazonian rivers (Cerdeira et al., 1997; Batista et al., 2004). Indeed, high fish consumption is a feature of the state of Amazonas, with several factors contributing to this dietary trend, such as the geographical location, indigenous culture, affordability of fish for all classes, and diversity of fish species.

Astronotus ocellatus (acará-açú) is a cichlid (Cichlidae) native to the Amazon River basin, including Brazil, Peru, Colombia, and French Guiana, and is economically important for aquarists, sport fishing, and as a food source (Soares et al., 2011). Pellona castelnaeana, commonly known as Amazon pellona, is one of the few species of the Pristigasteridae family recognized in commercial fishing and is important for subsistence fishing in the Amazon (Batista \& Petrere, 2003; Ikeziri et al., 2008). Leporinus friderici, known as the fat-headed aracu or piau (Characiformes, Anostomidae), is distributed throughout several South American countries (Paraguay, Argentina, Uruguay, Suriname, and Brazil), with environment and seasonal migration in a short space for reproduction in the filling period (Benedito-Cecílio et al., 2005; Graça \& Pavanelli, 2007; Agostinho et al., 2008; Ota et al., 2018). The three species studied are common and regularly occur in fish catches in the northern region of the Amazon. However, information about their chemical composition and body characteristics is scarce. These data are important for the development of appropriate technologies to regional fishing industry to achieve rational exploitation of natural fish stocks.

The Amazon is marked by a flood pulse, characterized by high waters (flood and flood peak) and low waters (dry season and ebb) (Sousa \& Freitas, 2008). The floods occur between December and June when shoals are formed, and spawning migrations occur in streams or lakes. At this time, abundant food is available and there are good connections between the waterways through which spawning fish and new recruits can move. The low water occurs from July to November when fish begin to leave flooded areas of the forest. As the volume of water reduces, the fish become more vulnerable to predation and

${ }^{1}$ Programa de Pós-graduação em Ciências Pesqueiras nos Trópicos, Universidade Federal do Amazonas - UFAM, Manaus, AM, Brasil

${ }^{2}$ Faculdade de Ciências Agrárias, Universidade Federal do Amazonas - UFAM, Manaus, AM, Brasil

${ }^{*}$ Corresponding author: baraialexandre@gmail.com 
are exposed to low oxygen concentrations in water and toxic compounds (Santos \& Santos, 2005).

The nutritional and commercial values of fish are directly related to the texture and chemical composition of their meat, yield, and factors related to origin, capture, and processing techniques (Machado \& Foresti, 2008; Araújo et al., 2018; Oliveira et al., 2020). Therefore, the study of the nutritional value of fish is not only important for the prescription of diets but also to establish the filet yield and the total waste generation, which are decisive factors for a fishing industry. Thus, the objective of this study was to evaluate meat yield, cuts yield and centesimal composition of the Amazonian fish species: A. ocellatus, $P$. castelnaeana, and $L$. friderici, in the dry and flood seasonal cycles of rivers.

\section{Materials and methods}

The species studied were obtained from the fish-landing port of CEASA-Manaus, located on BR-319, at the confluence of the Negro and Solimões rivers, where the water level of the rivers reaches its maximum peak in June (flood) and minimum level in November (dry season). In each cycle, a total of 60 fish were collected, comprising 20 specimens of each of the following species: A. ocellatus, P. castelnaeana, and $L$. friderici. The fish were preserved in ice boxes (1:1 ice:fish ratio) and transported to the Fish Technology Laboratory of the Federal University of Amazonas (Manaus, Brazil) for processing and laboratory analysis.

The specimens were measured using an ichthyometer and weighed on a digital electronic scale (Filizola ${ }^{\circ}$ brand, sensitivity of $2 \mathrm{~g}$ ) to obtain the total weight and the different cuts, for subsequent calculation of meat yield. The percentage yield was determined from the ratio of the weight of the cut (x100) to the weight of whole fish. The analysis of centesimal composition was performed according to norms recommended by the Association of Official Analytical Chemists (2005) and adopted by the Instituto Adolfo Lutz (2008) . The parameters measured were moisture, crude protein, total lipids, ash, and carbohydrates (by difference).
The results were submitted to the Shapiro-Wilk normality and Bartlett's homoscedasticity tests and statistically treated by two-way ANOVA. Means were compared by Tukey's test at $5 \%$ using R software version 3.1.3. (R Development Core Team, 2009).

\section{Results}

The yields of the different cuts of the studied species in different seasonal periods are presented in Table 1. A. ocellatus showed significant differences $(\mathrm{p}<0.05)$ in average weight, total residues, and in the gutted cuts, clean body, filet with skin, and filet without skin and head. P. castelnaeana species showed significant differences $(\mathrm{p}<0.05)$ in the average weight, clean body, and filet with skin. Leporinus friderici showed significant differences $(\mathrm{p}<0.05)$ in the average weight, total residues, clean body, filet without skin, and filet with skin. For P. castelnaeana and $L$. friderici, higher average weights were recorded during the flood period compared with A. ocellatus which had higher weights during the dry season. The head, along with the carcass, contributed the most to the final yield of the species in the periods.

The average results of the centesimal composition of the studied species are presented in Table 2. A significant difference $(\mathrm{p}<0.05)$ was found between seasonal periods for protein, lipids, and carbohydrates for A. ocellatus. For P. castelnaeana, significant differences $(\mathrm{p}<0.05)$ were observed between seasonal periods for moisture, protein, lipids, and carbohydrates. For $L$. friderici, significant differences $(\mathrm{p}<0.05)$ were found between seasonal periods for moisture, protein, lipids, ash, and carbohydrates.

Higher levels of protein and carbohydrates were found in the dry season for the three species. During the flood period, higher levels of lipids and ash were found for L. friderici and moisture for P. castelnaeana.

\section{Discussion}

The removal of fish offal is a necessary process in the storage and marketing of fish (Souza $\&$ Inhamuns, 2011). This practice aims to preserve the quality and organoleptic properties of fish. A 'clean body' refers to a fish specimen without the head, viscera,

Table 1. Yield values (mean \pm standard deviation) of the different cuts of A. ocellatus, P. castelnaeana, and L. friderici, during the flood and dry periods of the Amazon basin.

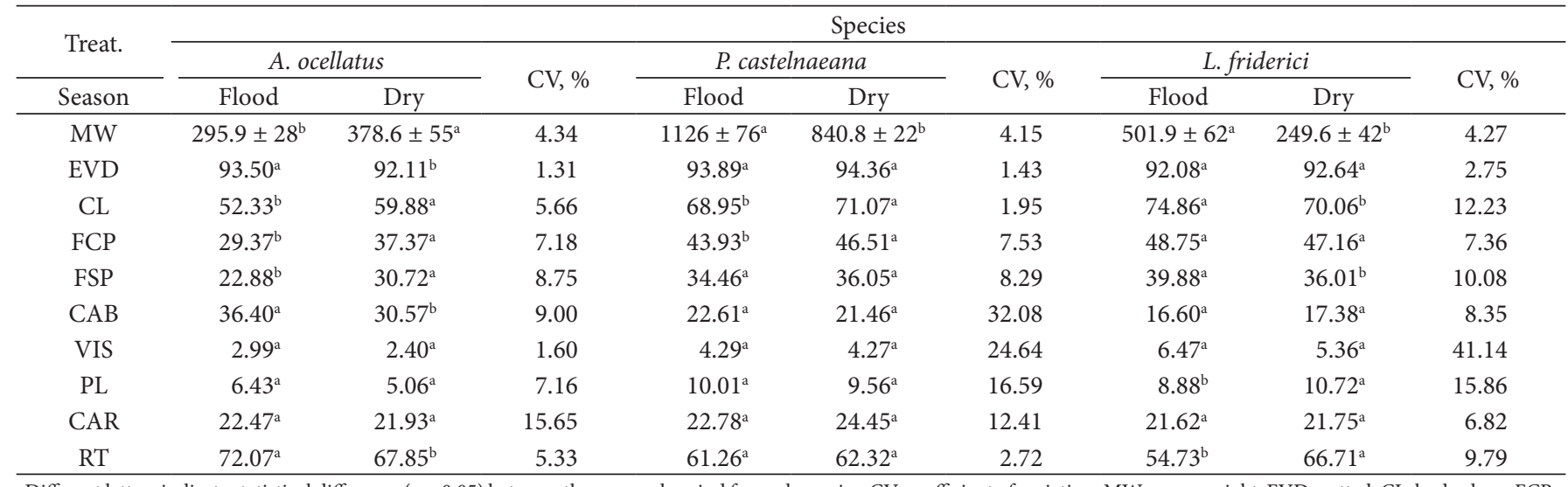

Different letters indicate statistical difference $(p<0.05)$ between the seasonal period for each species. CV: coefficient of variation; MW: mean weight; EVD: gutted; CL: body clean; FCP: filet with skin; FSP: filet without skin; CAB: head; VIS: viscera; PL: skin; CAR: carcass; RT: total waste. 
Table 2. Means of centesimal composition of A. ocellatus, P. castelnaeana, and L. friderici during flood and dry periods in the Amazon basin.

\begin{tabular}{|c|c|c|c|c|c|c|}
\hline \multirow{2}{*}{$\begin{array}{l}\text { Species } \\
\text { Season }\end{array}$} & \multicolumn{2}{|c|}{ A. ocellatus } & \multicolumn{2}{|c|}{ P. castelnaeana } & \multicolumn{2}{|c|}{ L. friderici } \\
\hline & Flood & Dry & Flood & Dry & Flood & Dry \\
\hline MS & $79.15^{\mathrm{a}} \pm 0.81$ & $78.98^{\mathrm{a}} \pm 0.25$ & $78.31^{\mathrm{a}} \pm 0.14$ & $73.32^{\mathrm{b}} \pm 0.34$ & $76.15^{b} \pm 0.22$ & $78.68^{a} \pm 0.38$ \\
\hline PRT & $18.82^{\mathrm{b}} \pm 0.27$ & $22.38^{\mathrm{a}} \pm 0.33$ & $18.53^{\mathrm{b}} \pm 1.07$ & $19.80^{\mathrm{a}} \pm 0.23$ & $18.16^{\mathrm{b}} \pm 0.54$ & $16.56^{\mathrm{a}} \pm 0.36$ \\
\hline FAT & $0.78^{\mathrm{b}} \pm 0.13$ & $1.21^{\mathrm{a}} \pm 0.18$ & $0.64^{\mathrm{b}} \pm 0.08$ & $5.08^{a} \pm 0.13$ & $3.94^{\mathrm{a}} \pm 0.30$ & $1.65^{\mathrm{b}} \pm 0.04$ \\
\hline ASH & $0.93^{a} \pm 0.01$ & $1.11^{\mathrm{a}} \pm 0.01$ & $1.19^{\mathrm{a}} \pm 0.03$ & $1.18^{\mathrm{a}} \pm 0.11$ & $1.07^{\mathrm{a}} \pm 0.05$ & $0.91^{b} \pm 0.02$ \\
\hline $\mathrm{CHO}$ & $0.31^{\mathrm{b}} \pm 0.00$ & $2.63^{\mathrm{a}} \pm 1.88$ & $1.36^{\mathrm{b}} \pm 0.79$ & $2.46^{\mathrm{a}} \pm 0.81$ & $0.66^{\mathrm{b}} \pm 0.44$ & $2.18^{a} \pm 0.04$ \\
\hline
\end{tabular}

fins, and scales. Of the three species studied, L. friderici had the highest average yield during the flood period. This finding can be attributed to its feeding habits, as it is an omnivorous species with a tendency to feed on insects or fruits, which are abundant during the flood period (Santos \& Santos, 2005; Delgado et al., 2020). In contrast, A. ocellatus showed higher yields during the dry season in the Amazon basin. This is a sedentary and omnivorous species, with a strong tendency to feed on small fish, insects, and crustaceans. In the dry season, the water volume is smaller, and these foods are easier to capture (Santos et al., 2006).

Oliveira \& Inhamuns (2003) found that silverfish (Cynoglossus semifasciatus), had an index of $68 \%$ for the clean body. This value was similar to that of $P$. castelnaeana during the dry season, and slightly higher than that of $A$. ocellatus during flood and the dry season. In keeping with the yield characteristics in a clean body, $L$. friderici and A. ocellatus presented the highest and lowest percentages for skin and filet cuts, both in the flood period. Values very close to those reported by this study were observed in mapará (Hypothalamus edentatus) and piramutaba (Brachyplatystoma vaillantii) (Souza \& Inhamuns, 2011; Oliveira \& Damasceno, 2014), and in matrinxã (Brycon cephalus) (Mujica et al., 2011). L. friderici is a fusiform species and tends to have higher yields because of its cylindrical muscle mass (Contreras-Guzmán, 1994), which can be processed in various ways. In fish, head size is inversely proportional to maximum yield (Morais et al., 1992; Contreras-Guzmán, 1994). In the present study, only A. ocellatus showed significant variation in the percentage of head during the seasonal cycle, the percentage being higher in the flood period. It is noteworthy that this species, when compared to L. friderici, which had the lowest values, presented approximately twice the percentage of head. A lower percentage of head was also found by Lima et al. (2011) for piau (L. obtusidens), which belongs to the same family (Anostomidae) as L. friderici. In another study, Souza \& Inhamuns (2011) found higher percentages of head for surubim (Pseudoplatystoma fasciatum) and tucunaré (Cichla monoculus) during the flood and dry seasons, respectively. However, these values were lower than those found for $A$. ocellatus in the present study.

Industrial fish processing produces a large amount of waste, most of which is not used for any other purpose and, depending on the fish species processed and the final product sought by the industry, can represent between $8 \%$ and $16 \%$ for gutted fish production and $60 \%$ to $72 \%$ for skinless filets (Kubitza, 2006). In carcass-yield studies of surubim (Pseudoplatystoma spp.) from two different production systems (net-pond and nursery), percentages were determined at $15.83 \% \pm 1.04 \%$ (Fantini et al.,
2013), while Lima et al. (2011) evaluated the yield for matrinxã carcasses at $36.5 \%$.

The morphometry of fish species influences the yield of filets and left-overs, and is data required by the fishing industry to avoid waste and add value to new byproducts. Studies by Araújo et al. (2018) evaluated the yields of traíra filets (Hoplias malabaricus) during the dry season and found they made up $34.62 \%$ to $34.76 \%$ of the total weight. Additionally, Mafra et al. (2016) reported a percentage yield of filet with skin of $44.79 \%$ to $48.60 \%$ for red piranha (Pygocentrus nattereri). These results were similar to those observed in this study for the P. castelnaeana and $L$. friderici during the flood and dry seasons, highlighting the potential of these species for the fishing industry.

Fish have a high nutritional importance in human food, and the chemical composition may vary between species and even within the same species, according to age, sex, and diet as well as the environment in which the animal is found. Fish muscle is made up of water, lipids, proteins, carbohydrates, minerals, and vitamins. These are important elements for human food intake and provide health benefits (Larsen et al., 2011; Sartori \& Amancio, 2012; Goes et al., 2016). In turn, the composition of the total lipid content, as well as the moisture content in fish, is a relevant factor because of the possibility of lipid oxidation and deterioration of fish quality between capture and consumer acquisition (Inhamuns et al., 2009).

In the Amazon region, there is marked seasonality in the moisture and fat levels of fish. During the flood season, fat levels are higher, reaching up to $15 \%$ in whole fish and $5 \%$ in filets, while moisture content can be between $65 \%$ and $75 \%$, respectively (Junk, 1985; Mafra et al., 2016; Araújo et al., 2018). Moisture and lipid content were inversely proportional in the dry season and flood period for the L. frederici and A. ocellatus. P. castelnaeana presented higher lipid content in the dry season, with respective reductions in muscle moisture. According to Claro-Jr et al. (2004), during the dry season, fish show greater variability in their diets. This is probably due to the scarcity of food in the environment, except for most piscivores, such as the $P$. castelnaeana, whose prey is more concentrated in bodies of water at this time of year. A. ocellatus was classified as thin in both seasonal periods, the P. castelnaeana was thin in the flood and semi-fat in the dry season, while L. friderici was classified as thin in the dry season and semi-fat in the flood, based on the work of Ackman (1989).

Meat contains more moisture than any other component and the higher the amount of moisture, the more susceptible the meat is to deterioration. Therefore, moisture has a direct effect on the 
color, juiciness, texture, taste, and stability of meat. The variations of moisture and lipid fractions in A. ocellatus were not significant, despite the increase in lipid content during the dry season. Lipids influence protein degradation, texture change, and intense flavor change, due to degradation of the unsaturated fatty acid chain; therefore, lipid content is considered an important attribute for evaluating fish quality (Figueiredo, 2009; Brito et al., 2019).

Machado \& Foresti (2008) stated that migratory fish, due to forced swimming during the piracema (spawning season), showed a decrease in lipid level and an increase in protein content when compared to resident species. This explains the lower lipid and protein levels in the dry season in L. friderici, as this is a migratory species, and the piracema begins in the dry season in the Amazon. A. ocellatus and apapá-yellow species showed higher protein and lipid values during the dry season. The former has an omnivorous carnivorous feeding habit, while the latter is carnivorous (Santos, 2006). The protein and lipid values are probably related to the periods of flood and the dry season when prey becomes more concentrated and easier to catch (Santos \& Santos, 2005). The percentage of ash ranged from $0.91 \%$ to $1.19 \%$ on average in the species studied. Only $L$. friderici presented significant differences between seasons, with the ash-percentage being lower in the dry season. It is important to mention that the determination of ash provides high quality information's about mineral elements and how the content is influenced by the food behavior of the species (Universidade Estadual de Campinas, 2011).

\section{Conclusion}

Seasonal variation influenced the centesimal composition and yield of the species studied, with significant differences between the cuts produced during processing. These findings highlight the need to apply a variety of technological processes to ensure efficient use of these species throughout the year. The total waste represented more than $50 \%$ of the whole fish, and the head size was directly proportional to the amount of waste generated. These results underscore the importance of waste utilization for animal and/or human nutrition.

\section{Acknowledgements}

The Student Program-Graduation Agreement-PEC-G / Milton Santos Project for the scholarship grant which made this work possible, Fundação de Amparo a Pesquisa do Estado do Amazonas-FAPEAM and Graduate Program of Fisheries Sciences in Tropics/UFAM by the support to develop this study, and Professor Dra. Gabriela Tomas Jerônimo (CIPET/UFAM), for the contributions made to this paper.

\section{References}

Ackman, R. G. (1989). Nutritional composition of fats in seafoods. Progress in Food \& Nutrition Science, 13(3-4), 161-289. PMid:2699043.

Agostinho, A. A., Pelicice, F. M., \& Gomes, L. C. (2008). Dams and the fish fauna of the Neotropical Region: impacts and management related to diversity and fisheries. Brazilian Journal of Biology = Revista Brasileira de Biologia, 68(4, Suppl.), 1119-1132. http:// dx.doi.org/10.1590/S1519-69842008000500019. PMid:19197482.
Araújo, C. K., Cirne, L. G. A., Souza, W. S., Silva, J. R., Feltran, R. B., Melo, D. R., Melo, P. R. R., \& Maciel, E. S. (2018). Características morfométricas, rendimento de filé e composição química da traíra. Agroecossistemas, 10(2), 25-36. http://dx.doi.org/10.18542/ragros. v10i2.5198.

Association of Official Analytical Chemists - AOAC. (2005). Official methods of analyses of the Association of Analytical Chemists (18th ed.). Arlington: AOAC.

Batista, V. S., \& Petrere, M. Jr. (2003). Characterization of the commercial fish production landed at Manaus, Amazonas State, Brazil. Acta Amazonica, 33(1), 53-66. http://dx.doi.org/10.1590/1809-4392200331066.

Batista, V. S., Issac, V. J., \& Viana, J. P. (2004). Exploração e manejo dos recursos pesqueiros da Amazônia. In M. L. Rufino (Ed.), A pesca e os recursos pesqueiros na Amazônia brasileira (pp. 63-152). Manaus: Ibama/ ProVárzea.

Benedito-Cecílio, E., Pereira, A. L., Baleroni, H., \& Faria, A. (2005). Effects of habitat on physiological indicators in Leporinus friderici (Pisces, Anostomidae) in the influence area of the Corumbá Reservoir, Goiás, Brazil. Acta Limnologica Brasiliensia, 17, 71-79.

Brito, B. M., Lira, G. M., Pinheiro, A. G. A., Santana, C. M. A. S., \& Amaral, I. L. (2019). Effect of cooking with interesterified margarine in the chemical composition of fish. Food Science and Technology, 39(Suppl. 2), 640-645. http://dx.doi.org/10.1590/fst.29618.

Cerdeira, R. G. P., Ruffino, M. L., \& Isaac, V. J. (1997). Consumo de pescado e outros alimentos pela população ribeirinha do lago grande de Monte Alegre, PA. Brasil. Acta Amazonica, 27(3), 213-227. http:// dx.doi.org/10.1590/1809-43921997273228.

Claro-Jr, L., Ferreira, E., Zuanon, J. G. J., \& Araújo-Lima, C. A. R. M. (2004). O efeito da floresta alagada na alimentação de três espécies de peixes onívoros em lagos de várzea da Amazônia Central, Brasil. Acta Amazonica, 34(1), 133-137. http://dx.doi.org/10.1590/S004459672004000100018.

Contreras-Guzmán, E. C. (1994). Biochemistry of fishery products. Jaboticabal: FUNEP.

Delgado, D. L. C., Rubio, C. A., \& Quiroz, V. A. C. (2020). Proximal and sensory analysis of red tilapia (Oreochromis sp.) fed with fish tanks sediments from a Biofloc culture. Food Science and Technology. In press. http://dx.doi.org/10.1590/fst.24520.

Fantini, L. E., Rodrigues, R. A., Nunes, A. L., Sanchez, M. S. S., Ushizima, T. T., \& Campos, C. M. (2013). Rendimento de carcaça de surubim (Pseudoplatystoma spp.) produzidos em tanque-rede e viveiro. Revista Brasileira de Saúde e Produção Animal, 14(3), 538-545. http://dx.doi. org/10.1590/S1519-99402013000300019.

Figueiredo, P. N. V. (2009). Perfil lipídico de cinco espécie de peixes capturados na Região do Oiapoque (Master's thesis). Universidade Estadual de Ceará, Fortaleza.

Goes, E. S. R., Souza, M. L. R., Michka, J. M. G., Kimura, K. S., Lara, J. A. F., Delbem, A. C. B., \& Gasparino, E. (2016). Fresh pasta enrichment with protein concentrate of tilapia: nutritional and sensory characteristics. Food Science and Technology, 36(1), 76-82. http://dx.doi.org/10.1590/1678-457X.0020.

Graça, W. J., \& Pavanelli, C. S. (2007). Peixes da planície de inundação do alto rio Paraná e áreas adjacentes. Maringá: EDUEM.

Ikeziri, A. A. S. L., Queiroz, L. J., Doria, C. R. C., Fávaro, L. F., Araujo, T. R., \& Torrente-Vilara, G. (2008). Estrutura populacional e abundância do Apapá-Amarelo, Pellona castelnaeana (Valenciennes, 1847) (Clupeiformes, Pristigasteridae), na Reserva Extrativista do Rio Cautário, Rondônia. Revista Brasileira de Zoociências, 10, 41-50.

Inhamuns, A. J., Franco, M. R. B., \& Batista, W. S. (2009). Seasonal variations in total fatty acid composition of muscles and eye sockets of 
tucunaré (Cichla sp.) from the Brazilian Amazon area. Food Chemistry, 117(2), 272-275. http://dx.doi.org/10.1016/j.foodchem.2009.03.113.

Instituto Adolfo Lutz (2008). Métodos físico-químicos para análise de alimentos (1020 p.). São Paulo: Instituto Adolfo Lutz.

Junk, W. J. (1985). Temporary fat storage, an adaptation of some species to the water level fluctuations and related environmental changes of the Amazon River. Amazônia, 9(3), 315-351.

Kubitza, F. (2006). Aproveitamento dos subprodutos do processamento de pescados. Panorama da Aqüicultura, 16(94), 23-29.

Larsen, R., Eilertsen, K. E., \& Elvevoll, E. O. (2011). Health benefits of marine foods and ingredients. Biotechnology Advances, 29(5), 508-518. http://dx.doi.org/10.1016/j.biotechadv.2011.05.017. PMid:21683131.

Lima, M. M., Mujica, P. Y. C., Lima, A. M., Santos, Y. L., Leite, M. S., \& Borges, R. G. (2011). Caracterização química e avaliação do rendimento em Filés de Piau (Leporinus obtusidens). In Anais do III Simpósio de Ciência e Tecnologia de Alimentos. Recife: SBCTA.

Lira, G. M., Lopez, A. M. Q., Nanes, G. M. de F., \& Silva, F. G. C. (2019). Chemical interaction between white onion, as natural antioxidant, on shrimp stored under freezing. Food Science and Technology, 39(Suppl. 2), 535-542. http://dx.doi.org/10.1590/fst.22218.

Lopes, J. C. S., Lima, R. M. L., Castro , W. O. Jr., Rufino, L. M., \& Oliveira, R. P. C. (2010). Comercialização e consumo do Pescado em São Luís de Montes Belos - GO. In Anais do VIIi Seminário de Iniciação Científica: Jornada de Pesquisa e Pós-graduação. Goiânia: Universidade Estadual de Goiás.

Machado, M. R. F., \& Foresti, F. (2008). Rendimento e composição química do filé de Prochilodus lineatus do Rio Mogi Guaçu, Brasil. Archivos de Zootecnia, 58(224), 663-670. http://dx.doi.org/10.21071/ az.v58i224.5056.

Mafra, D. P., Dresch, R. T., Costa, L. H. C., Costa, C. S., Klein, S., \& Diemer, O. (2016). Características morfométricas, rendimento corporal e composição química da piranha vermelha. Agrarian, 9(34), 383-389.

Morais, C., Mantovani, D. M. B., \& Carvalho, C. R. L. (1992). Yield and chemical composition of flesh ictiofauna to catch shrimp seven-beards (Xiphopenaeus kroyeri, heller, 1982). Coletâneas do ITAL, 22(1), 62-72.

Mujica, P. Y. C., Lima, M. M., Souza, J. R., Leite, M. S., Cornélio, T. F., \& Leite, Y. S. (2011). Caracterização química e avaliação do rendimento em filés de matrinchã (Brycon cephalus). In Anais do Congresso Brasileiro de Tecnologia de Carnes. São Pedro: ITAL.

Ogawa, M. (1999). O pescado como alimento. In M. Ogawa \& E. L. Maia (Eds.), Manual de pesca, ciência e tecnologia do pescado. São Paulo: Livraria Varela.

Oliveira, D. L., Grassi, T. L. M., Bassani, J. S., Diniz, J. C. P., Paiva, N. M., \& Ponsano, E. H. G. (2020). Enrichment of fishburgers with proteins from surimi washing water. Food Science and Technology, 40(4), 822-826. http://dx.doi.org/10.1590/fst.21319.
Oliveira, M. J. M., \& Inhamuns, A. J. (2003). Technological characterization of discus silver (Chaetobranchus semifasciatus) originating in the Amazon Basin. In Anais do XII Congresso de Iniciação Científica. Manaus: UFAM.

Oliveira, P. R., \& Damasceno, J. M. B. (2014). Propriedades químicas e rendimento da piramutaba (Brachyplatystoma vaillantii, Valenciennes, 1840). Pubvet, 8(14), 1698-1821. http://dx.doi.org/10.22256/pubvet. v8n14.1750.

Ota, R. R., Deprá, G. C., Graça, W. J., \& Pavanelli, C. S. (2018). Peixes da planície de Inundação do alto rio Paraná e áreas adjacentes: revised, annotated and updated. Neotropical Ichthyology, 16(2), e170094. http://dx.doi.org/10.1590/1982-0224-20170094.

R Development Core Team. (2009). $R$ : a language and environment for statistical computing. Vienna: R Foundation for Statistical Computing.

Santos, G. M., \& Santos, A. C. M. (2005). Sustentabilidade da pesca na Amazônia. Estudos Avançados, 19(54), 165-182. http://dx.doi. org/10.1590/S0103-40142005000200010.

Santos, G. M., Ferreira, E. J. G., \& Zuanon, J. A. S. (2006). Peixes comerciais de Manaus (2nd ed.). Manaus: Ibama/AM, ProVárzea.

Santos, R. N. (2006). Influência do ciclo hidrológico, maturação gonadal e categoria trófica no teor de peixes em uma área de várzea da Amazônia Central (Master's thesis). Instituto Nacional de Pesquisas do Amazonas, Universidade Federal do Amazonas, Manaus.

Sartori, A. G. O., \& Amancio, R. D. (2012). Pescado: importância nutricional e consumo no Brasil. Segurança Alimentar e Nutricional, 19(2), 83-93. http://dx.doi.org/10.20396/san.v19i2.8634613.

Soares, M. G. M., Costa, E. L., Siqueira-Souza, F. K., Anjos, H. D. B., Yamamoto, K. C., \& Freitas, C. E. C. (2011). Peixes de lagos do médio Rio Solimões (2nd ed.). Manaus: Reggo Edições.

Sousa, R. G., \& Freitas, C. E. C. (2008). The influence of flood pulse on fish communities of floodplain canals in the Middle Solimões River, Brazil. Neotropical Ichthyology, 6(2), 249-255. http://dx.doi. org/10.1590/S1679-62252008000200013.

Souza, L. F. A., \& Inhamuns, A. J. (2011). Análise de rendimento cárneo das principais espécies de peixes comercializadas no Estado do Amazonas, Brasil. Acta Amazonica, 41(2), 289-296. http://dx.doi. org/10.1590/S0044-59672011000200015.

Temesgen, M., Getahun, A., \& Lemma, B. (2019). Livelihood functions of capture fisheries in Sub-Saharan Africa: Food security, nutritional, and economic implications. Reviews in Fisheries Science \& Aquaculture, 27(2), 215-225. http://dx.doi.org/10.1080/23308249.2019.1565754.

Universidade Estadual de Campinas - UNICAMP. (2011). Tabela Brasileira de Composição de Alimentos: TACO (161 p.). Campinas: NEPA.

Verdi, R., Gasparino, E., Coradini, M. F., Chambo, A. P. S., Feihrmann, A. C., Goes, E. S. R., \& Souza, M. L. R. (2020). Inclusion of dehydrated mix of tilapia and salmon in pizzas. Food Science and Technology, 40(4), 794-799. http://dx.doi.org/10.1590/fst.22019. 